\title{
Factors Influencing Livability of Simmenthal Rearers from Birth to Transition Period
}

\author{
Levina Galina \\ Federal Government-funded Research Institution Federal \\ Science Center for Animal Husbandry named after \\ Academy Member L.K. Ernst \\ Moscow Oblast, Russia \\ gnlevina@yandex.ru
}

\author{
Khromova Lubove \\ Federal State Budgetary Educational Institution of Voronezh \\ Oblast, Voronezh State Agrarian University named after \\ Emperor Peter I \\ Voronezh, Russia \\ hromovva@yandex.ru
}

\begin{abstract}
This research is aimed at studying the diseases and livability of Simmenthal rearers (Kursk oblast, 4011 animals were born in 2012...2017) in a herd with the yield of more than 7 thousand kg of milk per animal. It has been determined that $3.8 \%$ of rearers died in the span from birth until the age of 6 months, including the $1.7 \%$ death loss in the first nine weeks of life where $0.65 \%$ died in the second week, and $0.32 \%$ died in the third week of life. In the first six months of life, $8.8 \ldots 12.9 \%$ more rearers died in summer and fall than in spring and winter. The percentage of diseases and death loss in the progeny by the Simmenthal bulls was different from that of the upgrades. For example, the Simmenthal progeny by the red Holstein bulls died along the entire 9 weeks of life, whilst the progeny of the Montbeliarde and Simmenthal bulls dies mostly in the first three weeks. The livability in the female calves is substantially lower than in the male calves.
\end{abstract}

Key words - Simmenthal, diseases and death of rearers, season, father bulls.

\section{INTRODUCTION}

Currently, the age of cows (both domestically and abroad) constitutes $2.5 \ldots 2.7$ of calving in the intense milking herds. Also, the lack of heifers is one of the key issues in milk production improvement. Therefore, rearing the healthy cattle is the decisive factor in improving the performance of animal husbandry.

Morbidity and mortality of newborn calves are usually due to a set of reasons; the main ones are the following: inadequate and unbalanced feeding of cows and heifers before calving, which leads to the birth of a

weak, physiologically immature, non-viable offspring, as well as to the secretion of grown animals, defective in physical, chemical and biological composition of colostrum and milk.

\author{
Nazarenko Alexander \\ Federal Government-funded Research Institution Federal \\ Science Center for Animal Husbandry named after \\ Academy Member L.K. Ernst \\ Moscow Oblast, Russia \\ naturproduct74@yandex.ru
}

\author{
Tikhonov Clement \\ Federal Government-funded Research Institution Federal \\ Science Center for Animal Husbandry named after \\ Academy Member L.K. Ernst \\ Moscow Oblast, Russia \\ Tikhon-k@mail.ru
}

The condition of a calf and the environment are in a very unstable balance, and if it is disturbed even by a small stressful situation (failure in feeding and maintenance, transportation, hypothermia, labeling, etc.), then the whole mechanism of pathological processes is started. It is important in the preservation of newborn calves to eliminate the social causes of morbidity, i.e. unsatisfactory conditions of feeding, maintenance and care. In animals that have undergone various diseases during pregnancy, temporary or prolonged deterioration of feeding and maintenance conditions and other adverse effects that deplete the body, a weaker and less viable offspring is born.

P.G. Svetlov was the first to scientifically formulate the critical phase theory [1] to state that each such critical phase predetermines the development of body functions and systems for the upcoming stage [2]. It has been discovered that the animal body does not fully implement all possibilities programmed in the genotype at each stage of the development [3].

Thus the focused and reasonable influences on the body on a critical phase may help implement the body's potential. The span from birth to two months of life is the most complicated one for the rearers. The said span may be subdivided into 2 periods: the newborn (colostral feeding) and suckling period (milk or calf milk replacer feeding until the age of two months) [4]. Each such period may be characterized by its specific physiology [5-6]. The early postnatal development is concurred with the evolvement of the immune and intestinal systems in calves [7]. The body systems in calves are generally immature and very sensitive to any changing ambience that they live in [8-11].

After birth, the calf from the sterile internal environment of the mother enters the surrounding external world, with various 
microflora, including pathogenic. A young organism needs to resist negative factors of environment on the background of the formation of the new independent functions of organs and systems - respiratory, blood, digestion, adaptation, etc. This should happen simultaneously with the formation of the immune system. In the body of newborn calves there are physiological processes that underlie the adaptation of animals to changing environmental conditions for 1-4 weeks.

In that period, the calves are greatly susceptible to ambient impacts and today's commercial livestock production technologies that directly affect the young calves where the immaturity of certain systems makes them highly sensitive to the said factors $[12,13]$.

It is common knowledge that the newborn animals constitute the majority of the ill and dead rearers [14]. With the large force of the negative factors and low resistance of the body, the pathological process begins and the first clinical signs of animal disease appear. If the negative force of the impact is small and resistance of the body high, then this is a physiological course of stress, but even in this case, stress causes significant damage to the animal and leads to poor health of all species and ages of farm animals. The deterioration of health is due to a decrease in the level of general resistance of the body due to the stress of metabolism and the need to adapt to new conditions of existence.

At the same time, additional adverse effects lead to aggravation or return of exhaustion and, as a rule, to the transition to pathology. Therefore, the cost of technology is the precursor to many diseases. The decrease in growth and development is associated with the additional use of energy resources and biologically active substances entering the body or biosynthesizing in it to maintain homeostasis and the formation of a new, more intense norm of its functioning.

Low safety of animals under stress is a consequence of metabolic disorders in the body and changes in the composition of its organs and tissues.

These are the early postnatal rearers that are mostly susceptible to the diseases and mortality [15]. During the first month of life, the greatest death of young animals is noted. Economic losses are significant not only because of the deaths of calves, but also because of the decrease in the intensity of growth, a longer period of recovery of surviving calves. This fact leads to an increase in costs, both for additional labor costs and veterinary drugs. High mortality rates among newborn calves are more common during the first 2 weeks of life. Later, the percentage of calves ' mortality decreases, but it can rise again when changing the type of feed.

This is also caused by a series of fairly objective things where the insufficiently developed immune protection, the inability of the intestine to digest albumen and others play the foremost role [16].

In recent years, numerous messages about the need to take actions to maintain livability of rearers have appeared in domestic literature [13-16, 17]. It is substantially explained by the fact that the major problem, as some researchers see it, is the neonatal mortality of rearers which varies from $8.7 \%$ to $6.4 \%$ in cattle worldwide [18]. Martin and Wiggins have counted that $20 \%$ mortality in calves resulted in $38 \%$ decrease of profit on a livestock farm [19]. The neonatal mortality in calves during the first month of life is as high as $84 \%$ of total mortality being the highest in the third week of life [20]. According to Afzal, the mortality in cattle calves has fluctuated between 29.1\% and 39.8\% [21]. In addition, any regular replacement of low yielders is impossible given there is medium $25 \%$ early mortality in rearers [22]. According to the US data, the mortality of dairy female calves constituted $7.8 \%$ in 2006 , of which $75 \%$ die during the first month of life [23].

Even higher mortality during the first three months of life has been observed, too. According to the researchers [24], the mortality in calves constituted $10.2 \%$ with $2.2 \%$ of dead-borns. In vealers, it varies from $2 \%$ to $20 \%$ [25].

With respect to the above, the rearers livability issue is becoming increasingly important causing the necessity to study and discover both the selective and paratypical factors that affect livability.

The aim of our research is to study the diseases and livability of rearers by season and gender with reference to Simmenthal upgrade paternal ancestry in a Simmenthal herd with the yield of more than 7.0 thousand $\mathrm{kg}$ of milk.

\section{OBJECTS AND METHODS OF RESEARCH}

The research was performed at Kursk Oblast agricultural business in Simmenthal rearers $(n=4011)$ born in 2012-2017. The livestock was retrospectively divided by first week diseases, seasons, gender, paternal breed.

The medium milk yield in the herd was 7.0..7.5 thousand $\mathrm{kg}$ during the study period with $3.97 \ldots 4.11 \%$ of fat and $3.13 \ldots 3.28 \%$ of albumen. The age of cows was about $2.7 \ldots 3.2$ calving.

\section{RESULTS AND THEIR DISCUSSION}

Out of 4,011 animals included in the research, $47 \%$ on average were female calves, and $53 \%$ were male calves. The largest female calf birth, in relation to average, was in February and July with the least declining on April and October (Table 1).

The largest epidemic among calves was in February, 16.1\% with the highest mortality from the disease constituting $60.9 \%$ of its medium value of $34.5 \%$ in spring.

As the research has shown, the maximum risk for the rearers occurs in the first weeks of life [11-13-26-27]. According to our data based on the $3.8 \%$ of dead animals, the high risk for the rearers occurred in the first 9 weeks where $1.7 \%$ of rearers died, whilst $0.65 \%$ of animals died when being transferred from colostral to milk feeding during the second week. And $0.32 \%$ of animals died after being transferred from milk to a replacer during week three. 
As to the season, the rearers had the most number of diseases in winter and summer $(12.4 \%$ and $11.3 \%)$, and the highest mortality occurred in summer and fall $(40.2 \%$ and $42.9 \%$ ) (Table 2).
Depending on the season, the death percentage was the highest in the second and third weeks of life (Table 3, Fig.1).

TABLE I. $\quad$ FEMALE TO MALE CALVES RATIO UPON BIRTH PER MONTH OF THE YEAR

\begin{tabular}{|c|c|c|c|c|c|c|c|c|c|c|c|c|c|c|}
\hline \multicolumn{2}{|c|}{ Months of the year: } & I & II & III & IV & $\mathbf{V}$ & VI & VII & VIII & IX & $\mathbf{X}$ & XI & XII & Total \\
\hline \multicolumn{2}{|c|}{ Total born, animals } & 375 & 267 & 413 & 356 & 357 & 377 & 300 & 360 & 333 & 315 & 312 & 246 & 4011 \\
\hline \multirow{2}{*}{ Including, $\%$} & female & 46 & 51 & 47 & 42 & 50 & 49 & 51 & 48 & 48 & 44 & 46 & 45 & 47 \\
\hline & male & 54 & 49 & 53 & 58 & 50 & 51 & 49 & 52 & 52 & 56 & 54 & 55 & 53 \\
\hline
\end{tabular}

TABLE II. DISEASES AND DEATHS OF REARERS BY SEASON

\begin{tabular}{|l|c|c|c|c|c|c|}
\hline \multirow{2}{*}{ Average per month in 6 years } & \multirow{2}{*}{ Born, animals } & \multicolumn{3}{|c|}{ Sick rearers, 0...6 months old } & \multicolumn{3}{|c|}{ Died rearers, 0..6 months old } \\
\cline { 3 - 7 } & & animals & \% & animals & \% of born & \% of ill \\
\hline winter & 888 & 110 & 12.4 & 33 & 3.7 & 30 \\
\hline spring & 1126 & 108 & 9.6 & 37 & 3.3 & 34.3 \\
\hline summer & 1037 & 117 & 11.3 & 47 & 4.5 & 40.2 \\
\hline fall & 960 & 84 & 8.8 & 36 & 3.8 & 42.9 \\
\hline TOTAL & 4011 & 419 & 10.4 & 153 & 3.8 & 36.5 \\
\hline
\end{tabular}

The analysis of Simmenthal rearers and calves by the upgrade bulls demonstrated the unstable nature of the disease against the genotype. Thus, the rearers by the Simmenthal bulls were more often ill in the first week of life when transferred from colostral to milk feeding: $5.3 \%$, which was the same during the three weeks, whilst only $3.0 \%$ calves by the Montbeliarde and red Holstein bulls fell ill in three weeks (Table 4).

TABLE III. REARERS LIVABILITY PER SEASON DURING THE FIRST 9 WEEKS OF LIFE

\begin{tabular}{|c|c|c|c|c|c|c|c|c|c|c|c|}
\hline \multirow{2}{*}{$\begin{array}{c}\text { On average in } 6 \\
\text { yrs }\end{array}$} & \multirow{2}{*}{ Born, animals } & \multirow{2}{*}{ Index } & \multicolumn{9}{|c|}{ Age, weeks } \\
\hline & & & 1 & 2 & 3 & 4 & 5 & 6 & 7 & 8 & 9 \\
\hline \multirow{2}{*}{ winter } & \multirow{2}{*}{888} & $\begin{array}{c}\text { died, } \\
\text { animals }\end{array}$ & & 11 & 5 & 2 & 2 & & & 1 & \\
\hline & & died, $\%$ & & 1.24 & 0.56 & 0.23 & 0.23 & & & 0.11 & \\
\hline \multirow[t]{2}{*}{ spring } & \multirow{2}{*}{1126} & $\begin{array}{c}\text { died, } \\
\text { animals }\end{array}$ & 4 & 9 & 4 & 1 & & & 3 & 1 & 1 \\
\hline & & died, $\%$ & 0.36 & 0.80 & 0.36 & 0.09 & & & 0.27 & 0.09 & 0.09 \\
\hline \multirow[t]{2}{*}{ summer } & \multirow{2}{*}{1037} & $\begin{array}{c}\text { died, } \\
\text { animals } \\
\end{array}$ & 1 & 3 & 1 & 1 & 3 & 2 & 2 & 2 & 1 \\
\hline & & died, $\%$ & 0.10 & 0.29 & 0.10 & 0.10 & 0.29 & 0.19 & 0.19 & 0.19 & 0.10 \\
\hline \multirow[t]{2}{*}{ fall } & \multirow{2}{*}{960} & $\begin{array}{c}\text { died, } \\
\text { animals }\end{array}$ & 3 & 3 & 3 & & & 2 & 1 & & \\
\hline & & died, $\%$ & 0.31 & 0.31 & 0.31 & & & 0.21 & 0.10 & & \\
\hline \multirow[t]{2}{*}{ total } & \multirow[t]{2}{*}{4011} & $\begin{array}{c}\text { died, } \\
\text { animals }\end{array}$ & 8 & 26 & 13 & 4 & 5 & 4 & 6 & 4 & 2 \\
\hline & & died, $\%$ & 0.20 & 0.65 & 0.32 & 0.10 & 0.12 & 0.10 & 0.15 & 0.10 & 0.05 \\
\hline
\end{tabular}




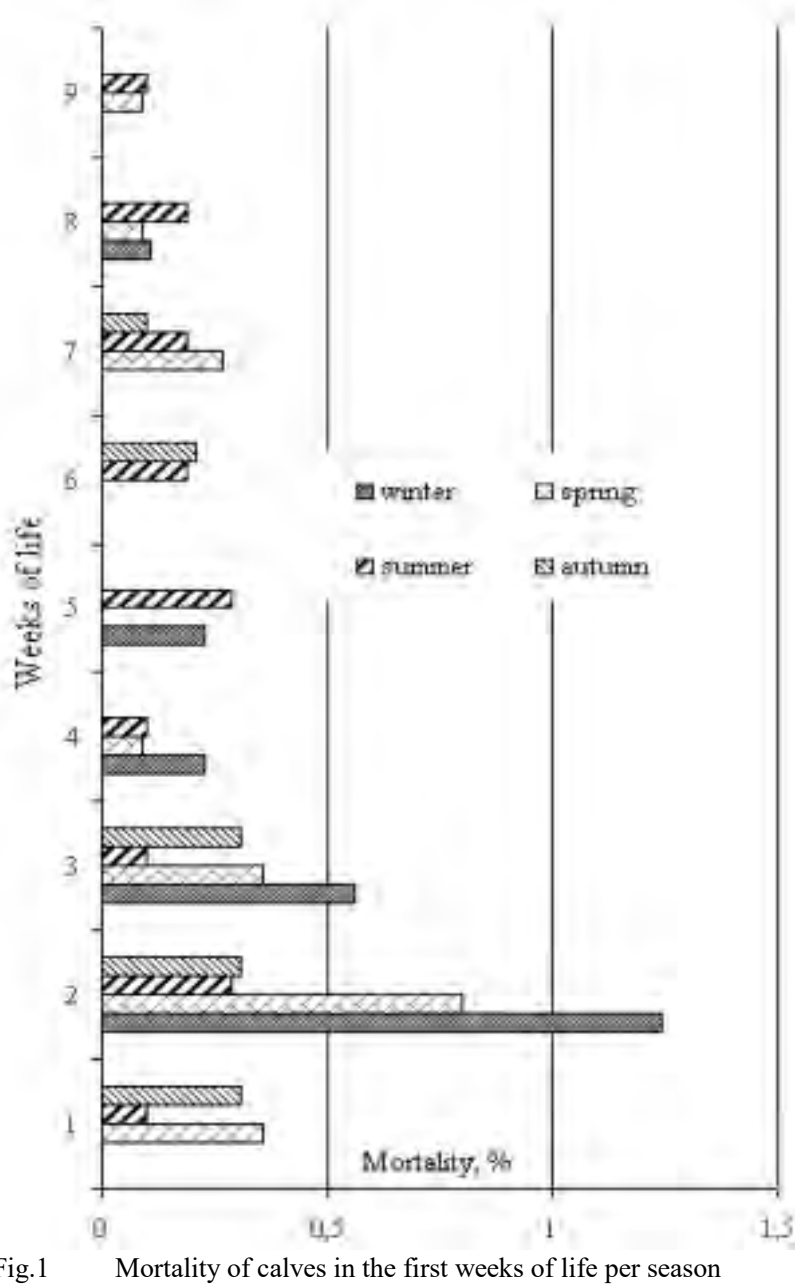

Having focused on the diseases and mortality in the Simmenthal calves descending from both Simmenthal bulls and upgrading bulls, we took tests in the paternal bulls with reference to the issues in question (Table 6). Thus, the progeny fell ill only in $39.4 \% \ldots 48.5 \%$ of 33 red Holstein father bulls in the first three weeks of life, and in $15.2 \ldots 21.2 \%$ the progeny fell ill each week of life from birth until week nine (Table.5).
Given the relation to the father's breed, the mortality of Simmenthal rearers per week of life had an unstable character the essence of which is that the progeny of Simmenthal bulls died during the second and third weeks only, which was basically the case also with the progeny of Montbeliarde bulls, and the progeny of red Holstein bulls just died. At the same time, $20 \ldots 40 \%$ of Montbeliarde father bulls $(n=5)$ had ill progeny, and the same amount of bulls had their progeny dead. Any discussion of Simmenthal father bulls would be inaccurate because there were only two of them. The male calves were more viable than females: the mortality rate among the former was $0.2 \%$ in the 9 weeks, and in the latter $-3.7 \%$ (Table 7 ).

Therefore, the analysis of the diseases and mortality in the rearers from birth to the transition period demonstrated that the said parameters were dependent on the season, feeding stresses in the first three weeks of life, gender, and origination from either directly Simmenthal father bulls or upgrading bulls. In addition, the progeny fells ill in the first weeks of life not with all paternal bulls.

\section{CONCLUSIONS}

Thus, the study of factors affecting the safety of young Simmental breed from birth to transition period, which was performed on 4011 animals born within six years in one agricultural enterprise, allowed establishing that the disease and mortality of young animals, which for 6 months was $3.8 \%$, was dependent on a number of factors. So by seasons of the year, when the most frequent disease of calves was observed in winter and summer (12.4\% and $11.3 \%$ of births), and mortality - summer and autumn (40.2\% and $42.9 \%$ of births). In addition, feed stress in the first three weeks of life in winter and spring periods adversely affected the safety of animals. After the transfer from colostrum to drinking milk, to the fall in the second week of life led to $0.65 \%$ of calves, and in the third week, after the transfer of animals from drinking milk to its substitute - fell to $0.32 \%$ of the offspring $(1.7 \%$ of the fallen in 9 weeks).

TABLE IV. DISEASES IN SEMMENTHAL CALVES BY UPGRADING BULLS IN THE FIRST WEEKS OF LIFE

\begin{tabular}{|c|c|c|c|c|c|c|c|c|c|c|c|c|}
\hline \multirow{2}{*}{ Father bulls } & \multirow[t]{2}{*}{ Calves born, animals } & \multirow[t]{2}{*}{ Index } & \multicolumn{9}{|c|}{ Age, weeks } & \multirow{2}{*}{ Total in 9 weeks } \\
\hline & & & 1 & 2 & 3 & 4 & 5 & 6 & 7 & 8 & 9 & \\
\hline \multirow{2}{*}{ Simmenthal $(n=2)$} & \multirow{2}{*}{114} & ill, animals & 6 & & & 1 & 1 & & & & & 8 \\
\hline & & ill, $\%$ & 5.3 & & & 0.9 & 0.9 & & & & & 7 \\
\hline \multirow{2}{*}{ Red Holstein, $(n=33)$} & \multirow{2}{*}{3668} & ill, animals & 52 & 42 & 20 & 24 & 15 & 23 & 14 & 17 & 14 & 221 \\
\hline & & ill, $\%$ & 1.4 & 1.1 & 0.5 & 0.7 & 0.4 & 0.6 & 0.4 & 0.5 & 0.4 & 6 \\
\hline \multirow{2}{*}{ Montbeliarde $(n=5)$} & \multirow{2}{*}{229} & ill, animals & 1 & 3 & 3 & & 2 & 1 & 4 & 3 & 1 & 18 \\
\hline & & ill, $\%$ & 0.4 & 1.3 & 1.3 & & 0.9 & 0.4 & 1.7 & 1.3 & 0.4 & 7.9 \\
\hline \multirow{2}{*}{ Total by 40 father bulls } & \multirow{2}{*}{4011} & ill, animals & 59 & 45 & 23 & 25 & 18 & 24 & 18 & 20 & 15 & 247 \\
\hline & & ill, \% & 1.5 & 1.1 & 0.6 & 0.6 & 0.4 & 0.6 & 0.4 & 0.5 & 0.4 & 6.2 \\
\hline
\end{tabular}


TABLE V.

MPRTALITY OF SIMMENTHAL CALVES AND CALVES BY UPGRADING BULLS IN THE FIRST WEEKS OF LIFE

\begin{tabular}{|c|c|c|c|c|c|c|c|c|c|c|c|}
\hline \multirow{2}{*}{ Father bull breed } & \multirow{2}{*}{ Calves born, animals } & \multirow{2}{*}{ Index } & \multicolumn{9}{|c|}{ Age, weeks } \\
\hline & & & 1 & 2 & 3 & 4 & 5 & 6 & 7 & 8 & 9 \\
\hline \multirow{2}{*}{ Simmenthal $(n=2)$} & \multirow{2}{*}{114} & animals & & 3 & 1 & & & & & & \\
\hline & & $\%$ & & 2.6 & 0.9 & & & & & & \\
\hline \multirow{2}{*}{ Red Holstein, $(n=33)$} & \multirow{2}{*}{3668} & animals & 8 & 20 & 11 & 4 & 5 & 4 & 6 & 3 & 2 \\
\hline & & $\%$ & 0.2 & 0.5 & 0.3 & 0.1 & 0.1 & 0.1 & 0.2 & 0.1 & 0.1 \\
\hline \multirow{2}{*}{ Montbeliarde $(\mathrm{n}=5)$} & \multirow{2}{*}{229} & animals & & 3 & 1 & & & & & 1 & \\
\hline & & $\%$ & & 1.3 & 0.4 & & & & & 0.4 & \\
\hline \multirow{2}{*}{ Total by 40 father bulls } & \multirow[t]{2}{*}{4011} & animals & 8 & 26 & 13 & 4 & 5 & 4 & 6 & 4 & 2 \\
\hline & & $\%$ & 0.2 & 0.6 & 0.3 & 0.1 & 0.1 & 0.1 & 0.1 & 0.1 & 0.05 \\
\hline
\end{tabular}

TABLE VI. BULLS (FROM N=40), WHOSE PROGENY WAS ILL AND DIED IN THE FIRST WEEKS OF LIFE

\begin{tabular}{|c|c|c|c|c|c|c|c|c|c|c|}
\hline \multirow{2}{*}{\multicolumn{2}{|c|}{ Index }} & \multicolumn{9}{|c|}{ Weeks } \\
\hline & & 1 & 2 & 3 & 4 & 5 & 6 & 7 & 8 & 9 \\
\hline \multirow[t]{2}{*}{ Total bulls whose progeny fell ill $(n=40)$, of which: } & animals & 18 & 16 & 15 & 10 & 12 & 14 & 11 & 8 & 12 \\
\hline & $\%$ & 45.0 & 40.0 & 37.5 & 25.0 & 30.0 & 35.0 & 27.5 & 20.0 & 30.0 \\
\hline - Simmenthal $(n=2)$ & $\%$ & 50.0 & & & 50.0 & 50.0 & & & & \\
\hline - red Holstein $(n=33)$ & $\%$ & 48.5 & 45.5 & 39.4 & 27.3 & 30.3 & 39.4 & 30.3 & 21.2 & 33.3 \\
\hline - Montbeliarde $(\mathrm{n}=5)$ & $\%$ & 20.0 & 20.0 & 40.0 & & 20.0 & 20.0 & 20.0 & 20.0 & 20.0 \\
\hline \multirow[t]{2}{*}{ Total bulls whose progeny died $(n=40)$} & animals & 8 & 7 & 9 & 4 & 3 & 6 & 3 & 4 & 2 \\
\hline & $\%$ & 20.0 & 17.5 & 22.5 & 12.5 & 7.5 & 15.0 & 7.5 & 10.0 & 5.0 \\
\hline - Simmenthal $(n=2)$ & $\%$ & 50.0 & 50.0 & & & & & & & \\
\hline - red Holstein $(n=33)$ & $\%$ & 21.2 & 15.2 & 21.2 & 12.1 & 9.1 & 18.2 & 9.1 & 12.1 & 6.1 \\
\hline - Montbeliarde $(n=5)$ & $\%$ & & 20.0 & 40.0 & & & & & & \\
\hline
\end{tabular}

TABLE VII. MORTALITY OF SIMMENTHAL CALVES PER GENDER

\begin{tabular}{|c|c|c|c|c|c|c|c|c|c|c|}
\hline \multirow{2}{*}{\multicolumn{2}{|c|}{ Index }} & \multicolumn{9}{|c|}{ Age, weeks } \\
\hline & & 1 & 2 & 3 & 4 & 5 & 6 & 7 & 8 & 9 \\
\hline \multicolumn{11}{|c|}{ Female calves } \\
\hline \multirow{2}{*}{$\begin{array}{c}\text { Females born, } \\
n=1,895\end{array}$} & animals & 6 & 26 & 13 & 4 & 5 & 4 & 6 & 3 & 2 \\
\hline & $\%$ & 0.3 & 1.4 & 0.7 & 0.2 & 0.3 & 0.2 & 0.3 & 0.2 & 0.1 \\
\hline \multicolumn{11}{|c|}{ Male calves } \\
\hline \multirow{2}{*}{$\begin{array}{c}\text { Males born, } \\
n=2,116\end{array}$} & animals & 2 & & & & 1 & & & 1 & \\
\hline & $\%$ & 0.1 & & & & 0.05 & & & 0.05 & \\
\hline
\end{tabular}

The gender characteristic had a significant impact on the safety of young animals in the first 9 weeks of life at a significant superiority of bull-calves, the percentage of disposal of which for this period was 0.2 , and heifers - 3.7.

Disease and mortality of offspring in the first weeks of life, depending on the belonging to the bulls of a particular breed, had some features. So $50 \%$ of the bulls of the Simmental breed offspring were eliminated only at the first and second weeks; in Montbeliarde bulls $(20 \% \ldots . .40 \%)$ the mortality of offspring was in the second and third weeks. Mortality of the bulls of the red Holstein $(6.1 \% \ldots 21.2 \%)$ offspring was during nine weeks, which shows a different level of viability of offspring, depending on the breed, both Simmental and breeds which improve it.

\section{References}

[1] P. G. Svetlov, "Theory of critical periods of development and its importance for understanding the principles of the environment on ontogenesis," Questions of. Cytology and General physiology, Moscow: Publishing house of the USSR, pp. 263-274, 1966. 
[2] L. P. Teltsov, I. R. Sasanow, "Critical phases of development of animals and practice animal husbandry," Fundamental and applied problems of increase of efficiency of agricultural animals, Saransk, pp. 52-53, 1998

[3] L. P. Teltsov, I. R. Shashanov, V. A. Zdorovenin, V. A. Stolyarov, "Laws of individual development of mammals, and practice," Journal of veterinary medicine, No. 1-2, pp. 3-9, 2007.

[4] J. C. Brearley, H. Dobson and R. S. Jones, "Investigations into the effect of two sedatives on the stress response in cattle," J. Vet. Pharmacol. Ther., Vol. 13, No. 4, pp.367-377, 1990.

[5] M. A. Sidorov, Yu. N. Fedorov "Immune status and infectious diseases of newborn calves and pigs," Veterinary, No. 11, pp.56-57, 2006

[6] M. W. Brunson and L. Huntsinger, "Ranching as a conservation strategy: can old ranchers save the new west?, vestigations into the effect of two sedatives on the stress response in cattle," Rangeland Ecology \& Management, vol. 61 (2), pp.137-147, 2008.

[7] A. A. Salikhov, V. I. Kosilov "Productive qualities of young black-andwhite breed," Bulletin of Oren-Burg State Agrarian University, No.1, pp. $64-65,2008$.

[8] V. I. Komlatsky, N. I. Kulikova, O. N. Eremenko et al, "Intensive breeding of calves, " Industrial standards, Krasnodar, p.111, 2009.

[9] S. S. Abramov "Prevention of non-communicable diseases of young animals," Moscow: Agropromizdat, pp. 5-17, 1990.

[10] K. P. Ivanov "General energy, heat exchange and thermoregulation," Leningrad: Science, p.312, 1990.

[11] J. C. Brearley, H. Dobson, R. S. Jones "Investigations into the effect of two sedatives on the stress response in cattle," Vet. Pharmacol. Ther, Vol. 13, No. 4, pp. 367-377, 1990

[12] J. W. Blum, C. R. Baumrucker, "Colostral and milk insulin-like growth factors and related substances: Mammary gland and neonatal targets," Dom is An Endocrinology, vol. 23, pp.101-110, 2002.

[13] G. N. Levina, E. V. Kalmit, "Growing of heifers of black-and-white breed with loose stok-keeping for highly productive herds using bulls of different breeding regions," Collection of L. K. Ernst vision, pp. 102-108, 2016

[14] L. E. Davis Rinker, M. J. VandeHaar, C. A. Wolf et al, "Effect of intensified feeding of heifer calves on growth, pubertal age, calving age, milk yield, and economics, ”J Dairy Sci, vol. 94, pp. 3554-3567, 2011.

[15] K. S. Bartlett, F. K. McKeith, M. J. VandeHaar et al, "Growth and body composition of dairy calves amounts of protein at two feeding rates," $\mathrm{J}$ Anim Sci, vol. 84, pp.1454-1467, 2006.
[16] A. Lyubimov, "Obtaining and cultivation of healthy calves," Agroinnovaciya, No. 4, pp. 18-19, 2007

[17] Yu. A. Makarov, "Mixed intestinal infections of newborn calves: recommendations," Academy of agricultural Sciences, Blagoveshchensk: Poly-M, p. 22, 2008.

[18] O. P. Danilkin, "The Physiology of stress of animals: method.instructions ", Krasnoyarsk: Krasnoyar. State. Agrar. Universitty, p. 32, 2016.

[19] S. J. Wells, L. P. Garber, G. W .Hill, "Health status of preweaned dairy heifers in the United States," Prev Vet Med., No. 29, pp.185-199, 1996.

[20] F. Bendali "Risk factors for neonatal diarrhea in beef calves," in Procc "Neonatal health in calves," Comprehensive solutions, 2009.

[21] A. M. K. Virtala, G. D. Mechor, Y. T. Grohn, N. E. Hollins, "Morbidity from non respiratory diseases and mortality in dairy heifers during the frst three months of life," Am Vet Med Assoc., p. 2043, 1996.

[22] M. Walther, "Principles of growing calves," Animal breeding, No. 1, pp.48-55, 2013.

[23] C. Svensson, K. Lundborg, U. Emanuelson, S.-O. Olsson, "Morbidity in Swedish dairy calves from birth to 90 days of age and individual calf-level risk factors for infectious diseases," Prev. Vet.Med., vol. 58 pp.179-197, 2003.

[24] A. Breda, A. Negash, A. Zewidu, B. Yaregal "Cross-Breed Calf Mortality and Farm Management Practices of Smallholder Dairy Farms," Journal of Biology, Agriculture and Healthcare., Vol. 6, No. 13, pp. 139-144, 2016.

[25] O. M. Radostits, D. C. Blood, C. C. Gray, "Veterinary Medicine: a textbook of disease of cattle, sheep, pig and horse," London:Bailer tyndal., No. 8, pp.857-883, 2007.

[26] S. N. Zolotukhin, L. P. Pulitserovskaya, H. P. Kavruk. "Nonspecific prophylaxis of mixed enteric infections of calves and piglets," Practices., No. 6, pp. 72-76, 2006.

[27] I. L. Leont'ev, "The Physiological status of calves in early postnatal ontogenesis and method of correction," Moscow: Ar-Konsalt, pp.4044, 2017.

[28] A. Khan, M. Z. Khan "Epidemiological aspects of neonatal calf mortality in the Nili-Ravi buffaloes," Pakistan Vet. J., vol. 15(4), pp.163-164, 1995.

[29] R. E. Kim, "Problems of infectious, invasive and non-infectious animal pathology in the non-Chernozem zone", In Proc.., Nizhny Novgorod, pp.170-174, 2001. 